\section{High Nutrient Concentrations of Hydroponic Solution Can Improve Growth and Nutrient Uptake of Spinach (Spinacia oleracea L.) Grown in Acidic Nutrient Solution}

\author{
Daniel P. Gillespie, Gio Papio, and Chieri Kubota \\ Department of Horticulture and Crop Science, The Ohio State University, \\ Columbus, OH 43210
}

Additional index words. acid, CEA, controlled environment, electrical conductivity, EC, deep water culture, DWC, $\mathrm{pH}$

\begin{abstract}
Hydroponic leafy green production offers high productivity and quality of crops but requires good management of $\mathrm{pH}$ and electrical conductivity (EC) to optimize the nutrient uptake. Nutrient solution $\mathrm{pH}$ is typically managed between 5.5 and 6.5, whereas lowering $\mathrm{pH}$ to more acidic range (e.g., $<5.0)$ can potentially mitigate problematic waterborne diseases. Plant response to low $\mathrm{pH}$ is species specific and generally involves direct effect of increased hydronium ions and indirect effects of $\mathrm{pH}$-dependent factors, such as low cations availability. To develop a new hydroponic nutrient management strategy, 'Corvair' spinach plants were grown under pH 4.0, 4.5, 5.0, and 5.5 of a hydroponic nutrient solution using a deep-water culture system in a growth chamber. Spinach shoot and root mass after 19 to 20 days declined with lowering $\mathrm{pH}$. At the lowest $\mathrm{pH}$ of 4.0, plants displayed stunted overall growth and severely inhibited root development. Plant growth and morphology at pH 4.5 or 5.0 were normal but small, suggesting that growth reduction at these $\mathrm{pH}$ was likely a result of reduced nutrient uptake. Plant tissue analyses showed decreased $\mathrm{N}, \mathrm{P}, \mathrm{K}, \mathrm{Mg}$, $\mathrm{S}, \mathrm{Cu}, \mathrm{Fe}, \mathrm{Mn}$, and $\mathrm{Zn}$ concentration as $\mathrm{pH}$ decreased. When the strength of nutrient solution was increased three times at a low $\mathrm{pH} 4.5$ to improve the overall nutrient availability, spinach shoot and root fresh weight with high nutrient concentrations (EC $3.4 \mathrm{dS} \cdot \mathrm{m}^{-1}$ ) significantly improved but was still lower than those in the control (pH 5.5 and EC $1.4 \mathrm{dS} \cdot \mathrm{m}^{-1}$ ), respectively. Plant tissue analysis showed that lowering pH to 4.5 significantly reduced tissue concentrations of $\mathrm{P}, \mathrm{K}, \mathrm{Ca}, \mathrm{Mg}, \mathrm{S}, \mathrm{Cu}, \mathrm{Mn}$, and $\mathrm{Zn}$ compared with those in the control. Under low $\mathrm{pH}$ and increased EC treatment (pH 4.5 and EC $3.4 \mathrm{dS} \cdot \mathrm{m}^{-1}$ ), all dry leaf nutrient concentrations were similar or higher than those of the control, except $\mathrm{Mg}$ and $\mathrm{Zn}$, which showed a lower concentration than the control with a weak significance $(P<0.06)$. This suggests that additional optimization of nutrient formula might further improve the spinach growth at low $\mathrm{pH}$. Together, our results will help to develop a new and low-cost nutrient management methodology to produce leafy greens hydroponically.
\end{abstract}

Increased demand for prewashed, prepackaged baby leaves of spinach (Spinacia oleracea) over the past decade has led to $51 \%$ increase in U.S. spinach production from 2012 to 2017 [Correll et al., 2011; U.S. Department of Agriculture National Agricu-

Received for publication 9 Feb. 2021. Accepted for publication 1 Apr. 2021.

Published online 27 May 2021.

We thank Mark Kroggel for technical support. This project was funded by the College of Food, Agricultural and Environmental Sciences, The Ohio State University, USDA NIFA SCRI (Award Number 2019-51181-30017) and Ohio Department of Agriculture Specialty Crop Block Grants.

C.K. is the corresponding author. E-mail: kubota.10 @osu.edu.

This is an open access article distributed under the CC BY-NC-ND license (https://creativecommons. org/licenses/by-nc-nd/4.0/). basilicum), and other leafy greens, most hydroponic operations, anecdotally, avoid growing spinach due to its susceptibility to Pythium spp. infection (Mattson, 2018).

Previous research introduced several mitigation strategies of Pythium and other oomycete disease control for spinach (e.g., Albright et al., 2007) and other hydroponically grown crops (e.g., Stanghellini, 1996). Recently, we showed that lowering $\mathrm{pH}$ of nutrient solution was a potential control measure for oomycete disease introduction using two cultivars of sweet basil (Gillespie, 2019; Gillespie et al., 2020). In these studies, we found that basil plants could uniquely tolerate $\mathrm{pH}$ as low as 4.0, whereas the same low $\mathrm{pH}$ was shown to lower the incidence of root rot disease caused by Pythium aphanidermatum. In fact, numerous studies have shown the negative effect of low $\mathrm{pH}(\mathrm{pH}<5.0)$ on oomycete sporangia development and zoospore motility (Blaker and MacDonald, 1983; Ho and Hickman, 1967; Kong et al., 2009). Although the conventional pH 5.5 to 6.5 (Savvas and Gruda, 2018) seems to be a range where almost all hydroponically grown crops exhibit normal growth and nutrient uptake, species-specific $\mathrm{pH}$ responses of leafy greens grown in liquid culture hydroponic systems is largely unexplored. Our general understanding is that nutrient disorders and thereby growth reduction occur when $\mathrm{pH}$ is outside the optimum range (Adams, 2002). Although commonly referenced $\mathrm{pH}$ nutrient availability charts indicate that micronutrients, such as $\mathrm{Cu}, \mathrm{Zn}, \mathrm{Mn}$, and $\mathrm{B}$ availability is increased with decreasing $\mathrm{pH}$ (Peterson, 1982), we found that nutrient uptake at low $\mathrm{pH}$ declined for many micro and macro elements in our previous experiments for sweet basil (Gillespie et al., 2020). When soilless substrates are used instead of liquid-based hydroponics, $\mathrm{pH}$ in the nutrient solution interacts with substrates (Dickson and Fisher, 2019), and micronutrient toxicity occurs rather than deficiency. Therefore, evaluation of plant's $\mathrm{pH}$ response must consider the growing systems employed.

Arnon and Johnson (1942) examined seven levels of $\mathrm{pH}$ (3.0-9.0) for lettuce and tomato plants grown hydroponically and showed significant reductions in shoot and root fresh weight below pH 5.0 for both species. However, because $\mathrm{pH}$ affects nutrient availability and nutrient uptake across plasma membrane, it is difficult to determine whether growth inhibition and nutrient disorders observed at low $\mathrm{pH}$ of the nutrient solution are a result of the direct effect of excessive hydronium ion concentration or $\mathrm{pH}$-dependent factors affecting nutrient availability and uptake. Nevertheless, studies suggest that the direct effect of $\mathrm{pH}$ seems to be detrimental only at the extreme ends of acidity and alkalinity, and growth reductions and nutrient disorders outside of the conventional $\mathrm{pH}$ ranges can typically be attributed to $\mathrm{pH}$-dependent factors (Arnon and Johnson, 1942; Bugbee, 2004; Gillespie et al., 2020; Islam et al., 1980; Mengel et al., 2001; Vlamis, 1953). Additionally, it has been reported that taking certain precautionary measures to account for $\mathrm{pH}$-dependent factors, 

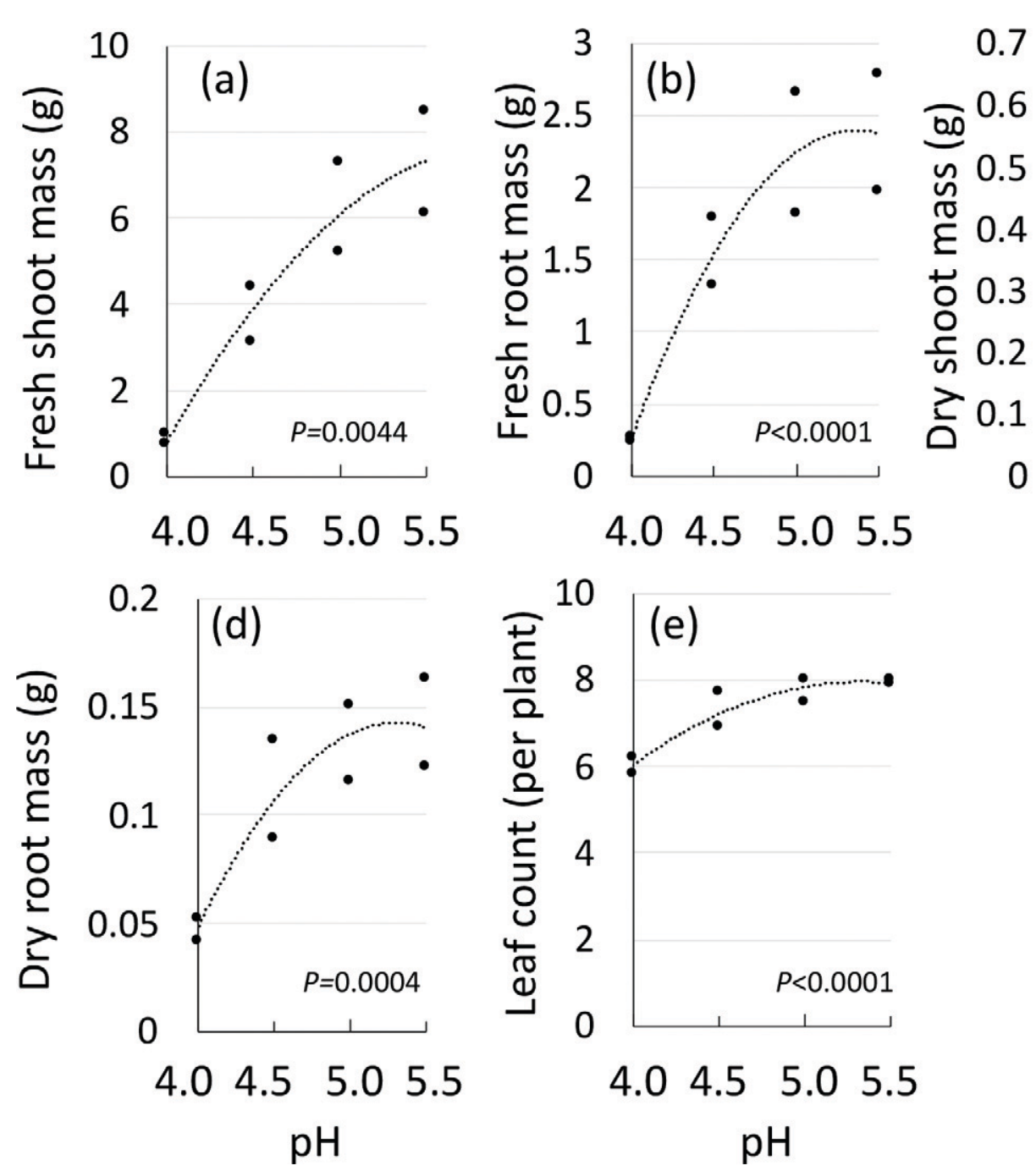

Fig. 1. Spinach plant growth responses to nutrient solution $\mathrm{pH}$ 4.0, 4.5, 5.0, or 5.5. Individual charts are (a) fresh shoot mass, (b) fresh root mass, (c) dry shoot mass, (d) dry root mass, and (e) leaf count per plant after 3 weeks. Means of 10 sample plants of two trials are shown. All responses were significant by analysis of variance $(P<0.15)$ and expressed with linear or quadratic regressions: (a) $y=-1.82 x^{2}+21.6 \times-56.6 ;(\mathbf{b}) y=-1.15 x^{2}+12.4 x-30.7 ;$ (c) $y$ $=-0.0919 x^{2}+1.18 x-3.15$; (d) $y=-0.0553 x^{2}+0.587 x-1.41$; (e) $y=-1.10 x^{2}+11.7 x-23.2$. Regression $P$ values are shown in each chart.

such as increasing nutrient concentrations in solution, may mitigate $\mathrm{pH}$-dependent factors affecting nutrient availability and uptake. For example, Arnon and Johnson (1942) reported that increasing calcium concentration improved tomato (Solanum lycopersicum) and lettuce growth at $\mathrm{pH} 4.0$ and 5.0. Another example by Smith et al. (2004) showed that the higher fertilizer concentrations ameliorated leaf chlorosis of geranium (Pelargonium $\times$ hortorum) plants caused by nutrient deficiencies at $\mathrm{pH} 7.0$ to 7.5 .

In the present study, we investigated how $\mathrm{pH}$ lower than the conventional range influences spinach plant growth and whether high nutrient concentrations can mitigate growth inhibition and nutrient disorders. Because interactions among uptake of different ions are

Table 1. Aerial environmental parameters recorded in Expts. 1 and 2 (each with two trials).

\begin{tabular}{lccrc}
\hline Trial & Air temp $\left({ }^{\circ} \mathrm{C}\right)$ & Water temp $\left({ }^{\circ} \mathrm{C}\right)$ & $\operatorname{VPD}^{\mathrm{z}}(\mathrm{kPa})$ & $P P F D\left(\mu \mathrm{mol} \cdot \mathrm{m}^{-2} \cdot \mathrm{s}^{-1}\right)^{\mathrm{y}}$ \\
\hline \multirow{5}{*}{1} & Day: $22.2 \pm 0.0$ & Day: $21.1 \pm 0.0$ & Day: $1.0 \pm 0.0$ & $312 \pm 1.2$ \\
& Night: $17.0 \pm 0.1$ & Night: $21.1 \pm 0.1$ & Night: $0.2 \pm 0.0$ & \\
2 & Day: $26.2 \pm 0.1$ & Day: $20.8 \pm 0.1$ & Day: $1.2 \pm 0.1$ & $324 \pm 1.9$ \\
& Night: $16.6 \pm 0.1$ & Night: $21.1 \pm 0.2$ & Night: $0.2 \pm 0.0$ & \\
& & Expt. 2 & & $365 \pm 5.1$ \\
& Day: $24.6 \pm 0.03$ & Day: $21.6 \pm 0.9$ & Day: $0.9 \pm 0.2$ & \\
& Night: $15.5 \pm 0.6$ & Night: $19.6 \pm 2.9$ & Night: $0.2 \pm 0.1$ & $346 \pm 3.5$ \\
& Day: $24.7 \pm 0.7$ & Day: $21.6 \pm 2.8$ & Day: $1.1 \pm 0.2$ & \\
& Night: $15.3 \pm 0.6$ & Night: $19.4 \pm 2.9$ & Night: $0.2 \pm 0.6$ & \\
\hline
\end{tabular}

${ }^{\mathrm{z}}$ Vapor pressure saturation deficit of air.

${ }^{\mathrm{y}}$ Photosynthetic photon flux density (spatial average measured at 40 locations before and after each trial).

complex and increasing hydronium ion concentrations (i.e., low $\mathrm{pH}$ ) further complicates the relationship, we took a simple approach of increasing the strength of nutrient solution as the first step toward optimization of nutrient formula for low $\mathrm{pH}$ applications. Specifically, we examined two strengths of total nutrient concentrations (measured by EC) to grow spinach plants under low $\mathrm{pH}$. Our hypotheses were 1) low $\mathrm{pH}$ would reduce nutrient uptake and affect spinach plant growth (Expt. 1) and 2) high nutrient concentrations of hydroponic solution would compensate for low uptake of specific nutrients and improve spinach growth in lower-than-conventional pH (Expt. 2).

\section{Materials and Methods}

Plant material, propagation, and water treatment. Spinach 'Corvair' seeds (Johnny's Selected Seeds, Fairfield, ME) were sown in rockwool sheets (AO plugs 200 counts, 2.5cm height; Grodan, Roermond, The Netherlands) on 4 Nov. 2018 and 29 Dec. 2018 for 
Expt. 1, and 31 July 2019 and 11 Sept. 2019 for Expt. 2. Before seeding, rockwool sheets were placed in white plastic undertrays and hydrated with reverse osmosis water containing $0.5 \mathrm{mg} \cdot \mathrm{L}^{-1}$ didecyl-dimethyl-ammonium chloride (KleenGrow, Pace Chemicals, Delta, $\mathrm{BC}$, Canada) and allowed to drain. After seeding, trays were placed inside a dark growth chamber set at $20^{\circ} \mathrm{C}$ air temperature.

For both experiments, except during germination and propagation, municipal water was used and was disinfected with ultraviolet radiation (D4 + Whole Home ultraviolet Water Disinfection System; Viqua, Guelph, ON, Canada). Water used in DWC units was also dechlorinated by the addition of $2.5 \mathrm{mg} \cdot \mathrm{L}^{-1}$ of sodium thiosulfate. This was done to avoid chlorine phytotoxicity from municipal source water that has been observed in our past experiments. Our water quality analyses typically show low levels of $\mathrm{Ca}\left(<30 \mathrm{mg} \cdot \mathrm{L}^{-1}\right), \mathrm{Cl}$ $\left(<30 \mathrm{mg} \cdot \mathrm{L}^{-1}\right), \mathrm{NO}_{3}-\mathrm{N}\left(<3 \mathrm{mg} \cdot \mathrm{L}^{-1}\right), \mathrm{Mg}(<8$ $\left.\mathrm{mg} \cdot \mathrm{L}^{-1}\right), \mathrm{S}\left(<20 \mathrm{mg} \cdot \mathrm{L}^{-1}\right), \mathrm{K}\left(<5 \mathrm{mg} \cdot \mathrm{L}^{-1}\right), \mathrm{P}$ $\left(<0.5 \mathrm{mg} \cdot \mathrm{L}^{-1}\right), \mathrm{Zn}\left(<0.5 \mathrm{mg} \cdot \mathrm{L}^{-1}\right), \mathrm{Na}(<20$ $\left.\mathrm{mg} \cdot \mathrm{L}^{-1}\right)$ and $\mathrm{Al}\left(<0.2 \mathrm{mg} \cdot \mathrm{L}^{-1}\right)$. Alkalinity is typically $<42.0 \mathrm{CaCO}_{3} \mathrm{mg} \cdot \mathrm{L}^{-1}$ and approximate $\mathrm{EC}$ is 0.2 to $0.3 \mathrm{dS} \cdot \mathrm{m}^{-1}$.

After radical emergence was observed, seeded trays were moved to the conditions of $25 / 15^{\circ} \mathrm{C}$ day/night air temperatures and $12 \mathrm{~h} /$ $\mathrm{d}$ photoperiod inside a growth chamber (GR96, Conviron, Winnipeg, MB, Canada). Light source in chamber were white fluorescent lamps (Master TL5 54W/840; Philips, Amsterdam, The Netherlands). Seedlings were subirrigated with water as needed until transplanting. The $\mathrm{pH}$ of water provided to seedlings before transplant was $\approx 6.4$. When cotyledons were fully expanded, uniform plants with rockwool substrate (15 to $20 \mathrm{~mL}$ ) were transplanted into DWC units (11 Nov. 2018 and 12 Jan. 2019 for Expt. 1; 9 Aug. 2019 and 25 Sept. 2019 for Expt. 2).

In both experiments, T-type thermocouples were placed at the middle of each side of the chamber for monitoring air temperature at plant canopy level (gauge 36; Omega Inc., Stamford, CT) and nutrient solution temperature (gauge 24; Omega Inc.). Relative humidity was measured with a temperature/ humidity probe (HMP60 Humidity and Temperature Probe; Vaisala Corporation, Helsinki, Finland) housed inside an aspirated shield located in the middle of the growth chamber at plant canopy level. Sensors were connected to a datalogger (CR10X dataloggers; Campbell Scientific, Logan, UT) and sensor readings were scanned every $10 \mathrm{~s}$ to record averages each $15 \mathrm{~min}$. Vents of the growth chamber were kept open for sufficient outdoor makeup air to provide ambient $\mathrm{CO}_{2}$ conditions inside the room.

Expt. 1: Effects of nutrient solution $\mathrm{pH}$ on spinach plant growth and nutrient uptake. There were four DWC units each with 0.78 $\mathrm{m}$ long, $0.51 \mathrm{~m}$ wide, and $0.37 \mathrm{~m}$ tall black plastic container (Centrex Plastics, LLC Commander 27-Gallon Black Tote; Centrex Plastics, Findlay, $\mathrm{OH}$ ) and a polystyrene foam raft (Beaver Plastics 72"; Beaver Plastics, Acheson, AB, Canada) cut to match the size of container. Each DWC unit contained 24 plants in $90 \mathrm{~L}$ of nutrient solution made using dechlorinated and ultraviolet radiated water as described previously. The large volume to plant ratio ( $3.75 \mathrm{~L}$ per plant) was to act as a buffer in attempts to minimize $\mathrm{pH}$ fluctuations. Nutrient solution was continuously aerated by one air stone connected to a small aquarium air pump.

One-half strength University of Arizona leafy crop nutrient solution recipe (Jensen, unpublished) was used as the basal formula in this experiment. This formula contains $\left(\mathrm{mg} \cdot \mathrm{L}^{-1}\right) 90 \mathrm{NO}_{3}-\mathrm{N}, 25 \mathrm{P}, 99 \mathrm{~K}, 100 \mathrm{Ca}, 20$ $\mathrm{Mg}, 1.0 \mathrm{Fe}$ (DPTA-chelated), $0.3 \mathrm{Mn}, 0.2 \mathrm{Zn}$, $0.03 \mathrm{Cu}, 0.2 \mathrm{~B}$, and $0.03 \mathrm{Mo}$. Before transplant, nutrient solution $\mathrm{pH}$ was adjusted to setpoints 4.0, 4.5, 5.0, and 5.5 using sulfuric acid. After that, $\mathrm{pH}$ was monitored at minimum once per day and manually adjusted thereafter as needed by the addition of sulfuric acid or sodium hydroxide to maintain $\mathrm{pH}$ within a range of \pm 0.25 of target $\mathrm{pH}$. ECs and dissolved oxygen (DO) of each DWC unit were measured at least three times a week. Handheld meters ( $\mathrm{pH} / \mathrm{EC}$ Combo Meter, Bluelab, Tauranga, New Zealand; 407510 DO meter, Extech, Nashua, $\mathrm{NH}$ ) were used for $\mathrm{pH}, \mathrm{EC}$, and DO measurements. EC and $\mathrm{pH}$ meters were calibrated weekly. Nutrient solutions were sent to a commercial analytical laboratory (JR Peters, Allentown, PA) for microand macronutrients at the end of experiment.

This experiment was replicated over time (Trials 1 and 2). Twenty days (Trial 1) or 19 d (Trial 2) after transplanting, plants were harvested for quantifying plant growth and assessing visible symptoms of nutrient disorders. Fresh/dry shoot and root mass and number of leaves per plant were recorded for 10 randomly sampled plants per $\mathrm{pH}$ treatment. Roots were separated from rockwool and carefully dried with paper towels consistently throughout, before fresh weight measurement. Following fresh weight measurements, plant material was dried in a drying oven at $55^{\circ} \mathrm{C}$ for a minimum of 1 week. Once dry mass was measured, leaf tissue samples of all 10 plants were combined into one sample and sent to the same commercial analytical laboratory to determine nutrient concentrations of leaf tissue.

All data of Trials 1 and 2 were compiled and analyzed as one data set. Location of $\mathrm{pH}$ treatments were randomized each replication so that no treatments were located in the same place inside the growth chamber. Plant growth data (fresh/dry mass and leaf number) and leaf nutrient concentration data were evaluated using an analysis of variance (ANOVA) and linear or quadratic regression analysis was applied when ANOVA $F$-test was significant $(P<0.15)$. All statistical analyses were performed using JMP software (Ver. 14; SAS Institute, Cary, NC).

Expt. 2: Effects of increased nutrient concentrations on spinach growth and nutrient uptake under low pH. Expt. 2 employed four treatments consisting of $\mathrm{pH}(4.5$ or 5.5$)$ and EC $\left(1.4\right.$ or $\left.3.4 \mathrm{dS} \cdot \mathrm{m}^{-1}\right)$ of the nutrient solution using smaller DWC units $(36.2 \mathrm{~cm}$ tall and

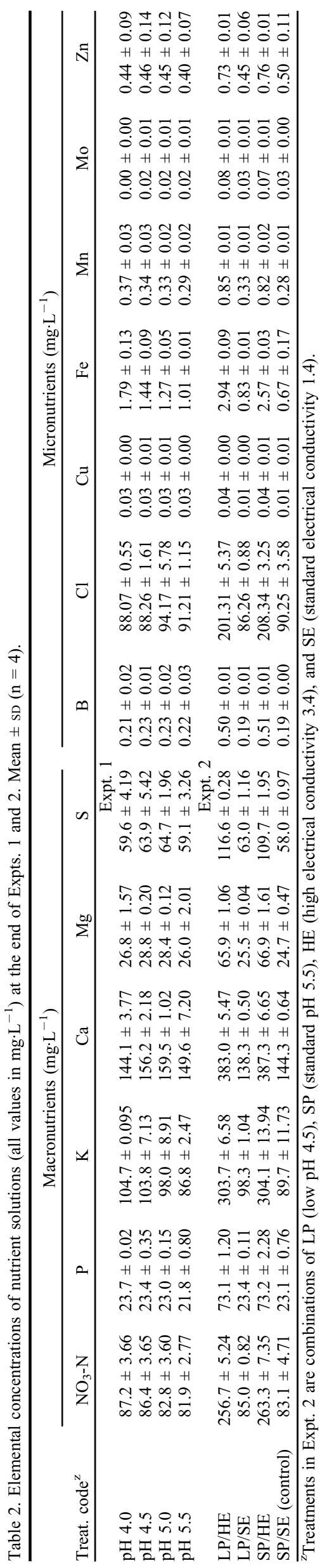


$31.8 \mathrm{~cm}$ diameter; United Solutions 5-gallon Residential Bucket, Lowes, Mooresville, NC) each with a polystyrene foam raft (Kingspan Insulation, $1.9 \mathrm{~cm} \times 1.2 \mathrm{~m} \times 2.4 \mathrm{~m} \mathrm{R}-4 \mathrm{Un}$ face Polystyrene Foam Board Insulation, Winchester, VA) cut to match the size of bucket. Three holes of the size of rockwool cubes (diameter: $2.5 \mathrm{~cm}$ ) were cut into each raft (three plants per raft). Each DWC unit (16 units in total) contained $15 \mathrm{~L}$ of nutrient solution made using dechlorinated and ultraviolet-treated water.

Following Expt. 1, the same nutrient solution recipe was used as the basal formula in this experiment. Additionally, three times higher strength of nutrient solution was examined by adjusting dilution rate of the stock solutions. The resulting EC after mixing with ultraviolet-treated dechlorinated water was either 1.4 or $3.4 \mathrm{dS} \cdot \mathrm{m}^{-1}$. Before transplant, nutrient solution $\mathrm{pH}$ was adjusted to setpoints 4.5 or 5.5 using sulfuric acid. At least once a day, $\mathrm{pH}$ was monitored and manually adjusted thereafter as needed by adding sulfuric acid to maintain $\mathrm{pH}$ within a range of \pm 0.25 of target $\mathrm{pH}$. At least three times a week, EC and DO of each DWC unit were measured using the same handheld meters as described before. Nutrient solutions were sent to the same commercial analytical laboratory (JR Peters, Allentown, PA) for micro- and macronutrients at the end of experiment. Twenty days after transplanting, all plants were harvested for quantifying plant growth and nutrient concentrations in the same procedures as in Expt. 1.

This experiment was conducted twice (Trial 1 and 2) each with the four treatments replicated in four blocks inside the growth chamber. Because there were no interactions by trial, plant growth and nutrient data were pooled $(\mathrm{n}=8)$ and subjected to ANOVA followed by $t$ test paired with the control (standard $\mathrm{EC}$ and $\mathrm{pH}$ ) and between standard and high $\mathrm{EC}$ at low $\mathrm{pH}$. All statistical analyses were performed using JMP software (SAS Institute).

\section{Results and Discussion}

Environmental conditions. Average day and night growth chamber air temperatures, nutrient solution temperatures, vapor pressure deficient (VPD), and photosynthetic photon flux density are reported in Table 1 . All setpoints were maintained within an acceptable range throughout the experiments. Measured nutrient concentrations in solution at the end of the experiments are reported in Table 2 . All macro- and micronutrients were at comparable levels between $\mathrm{pH}$ treatments in Expt. 1. In Expt. 2, all macronutrient concentrations except S remained 2.6 to 3.4 times higher in high EC treatments (marked as $\mathrm{HE}$ ). The S concentration was only 1.9 times greater in high EC treatments likely because of the difference in the amount of sulfuric acid used for $\mathrm{pH}$ adjustment. Micronutrient concentrations except $\mathrm{Cl}$ and $\mathrm{Zn}$ were 2.6 to 4 times higher in high EC treatments than low EC treatments. $\mathrm{Cl}$ and $\mathrm{Zn}$ concentrations
Table 3. Root-zone environmental parameters recorded in Expts. 1 and 2 (each with two replications). Mean \pm SD of daily measurements.

\begin{tabular}{|c|c|c|c|c|}
\hline Trial & Treatment code ${ }^{z}$ & $\mathrm{pH}$ & $\mathrm{EC}\left(\mathrm{dS} \cdot \mathrm{m}^{-1}\right)$ & $\begin{array}{l}\text { Dissolved oxygen } \\
(\mathrm{ppm})\end{array}$ \\
\hline & & Expt. & & \\
\hline \multirow[t]{4}{*}{1} & $\mathrm{pH} 4.0$ & $4.03 \pm 0.09$ & $1.44 \pm 0.06$ & $9.04 \pm 0.16$ \\
\hline & $\mathrm{pH} 4.5$ & $4.56 \pm 0.11$ & $1.49 \pm 0.04$ & $8.88 \pm 0.21$ \\
\hline & pH 5.0 & $5.01 \pm 0.29$ & $1.49 \pm 0.03$ & $8.87 \pm 0.21$ \\
\hline & pH 5.5 & $5.44 \pm 0.26$ & $1.39 \pm 0.04$ & $8.99 \pm 0.22$ \\
\hline \multirow[t]{4}{*}{2} & $\mathrm{pH} 4.0$ & $4.04 \pm 0.11$ & $1.42 \pm 0.04$ & $9.13 \pm 0.29$ \\
\hline & $\mathrm{pH} 4.5$ & $4.47 \pm 0.17$ & $1.41 \pm 0.03$ & $9.03 \pm 0.28$ \\
\hline & pH 5.0 & $4.96 \pm 0.14$ & $1.41 \pm 0.04$ & $9.06 \pm 0.43$ \\
\hline & $\mathrm{pH} 5.5$ & $\begin{array}{r}5.47 \pm 0.11 \\
\text { Expt. }\end{array}$ & $1.40 \pm 0.00$ & $9.12 \pm 0.30$ \\
\hline \multirow[t]{4}{*}{1} & $\mathrm{LP} / \mathrm{HE}$ & $4.72 \pm 0.01$ & $3.43 \pm 0.01$ & $7.23 \pm 0.32$ \\
\hline & $\mathrm{LP} / \mathrm{SE}$ & $4.75 \pm 0.02$ & $1.42 \pm 0.01$ & $7.06 \pm 0.33$ \\
\hline & $\mathrm{SP} / \mathrm{HE}$ & $5.54 \pm 0.01$ & $3.38 \pm 0.01$ & $7.13 \pm 0.31$ \\
\hline & SP/SE (control) & $5.58 \pm 0.02$ & $1.40 \pm 0.01$ & $7.25 \pm 0.33$ \\
\hline \multirow[t]{4}{*}{2} & $\mathrm{LP} / \mathrm{HE}$ & $4.63 \pm 0.01$ & $3.43 \pm 0.01$ & $6.54 \pm 0.13$ \\
\hline & $\mathrm{LP} / \mathrm{SE}$ & $4.69 \pm 0.01$ & $1.39 \pm 0.01$ & $6.78 \pm 0.22$ \\
\hline & $\mathrm{SP} / \mathrm{HE}$ & $5.52 \pm 0.06$ & $3.43 \pm 0.01$ & $6.50 \pm 0.36$ \\
\hline & SP/SE (control) & $5.54 \pm 0.01$ & $1.40 \pm 0.00$ & $6.57 \pm 0.20$ \\
\hline
\end{tabular}

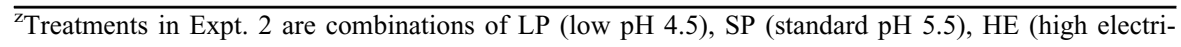
cal conductivity 3.4 ), and SE (standard electrical conductivity 1.4 ). were only 1.5 to 2.3 times greater in high EC treatments. Average $\mathrm{pH}, \mathrm{EC}$, and DO of experimental nutrient solutions are reported in Table 3 and were in the target ranges of the experiments.

Effects of pH of nutrient solutions on spinach growth and nutrient uptake (Expt. 1). All spinach growth parameters measured in this experiment (shoot and root fresh/dry mass, and leaf count per plant) declined as lowering $\mathrm{pH}$ (Fig. 1). Fresh shoot mass (i.e., yield) of spinach was $0.88 \mathrm{~g}(12 \%)$ and $3.8 \mathrm{~g}(52 \%)$ per plant (averages of two trials) at $\mathrm{pH} 4.0$ and 4.5 , respectively, compared with those at the standard pH 5.5 (7.3 g per plant). Similarly, fresh root mass, dry shoot mass, and dry root mass (all per plant) were $0.26 \mathrm{~g}(11 \%)$, $0.12 \mathrm{~g}(21 \%)$, and $0.047 \mathrm{~g}(33 \%)$ at $\mathrm{pH} 4.0$,
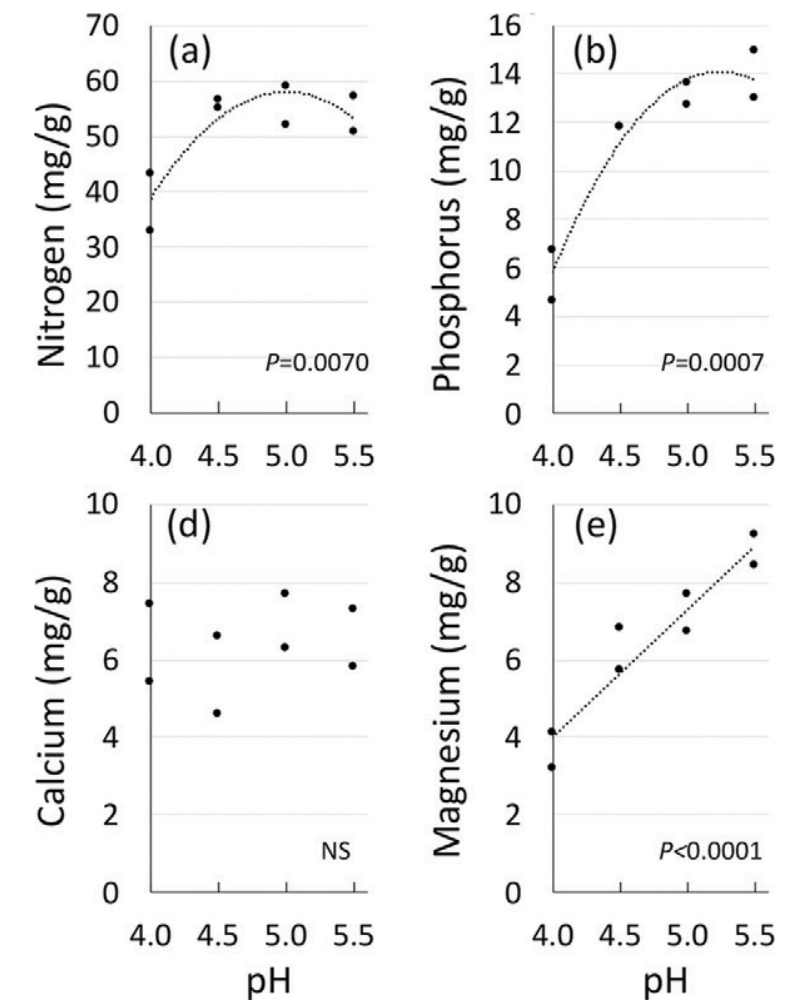
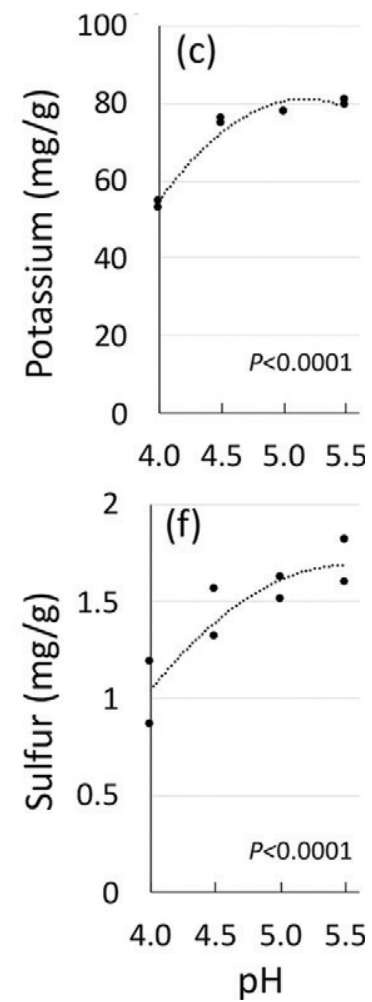

Fig. 2. Responses of leaf nutrient concentrations of spinach plants to nutrient solution $\mathrm{pH} 4.0,4.5,5.0$, or 5.5 (Expt. 1). Responses significant by analysis of variance $(P<0.15)$ were expressed with linear or quadratic regressions: (a) $y=-19.3 x^{2}+193 x-424$; (b) $y=-5.35 x^{2}+56.1 x-132$; (c) $y=-19.2$ $x^{2}+198 x-431 ;$ (d) NS; (e) $y=3.28 x-9.11$; (f) $y=-0.272 x^{2}+3.02 x-6.67$; (g) NS; (h) $y=$ $0.926 x-2.109$; (i) $y=18.5 x-9.34$; (j) $y=22.1 x-48.1$; (k) NS; (l) $y=-94.3 x^{2}+1013 x-2481$; (m) $y=-277 x+1692$. Regression $P$ values (NS $=$ nonsignificant at $P<0.05)$ are shown in each chart. 

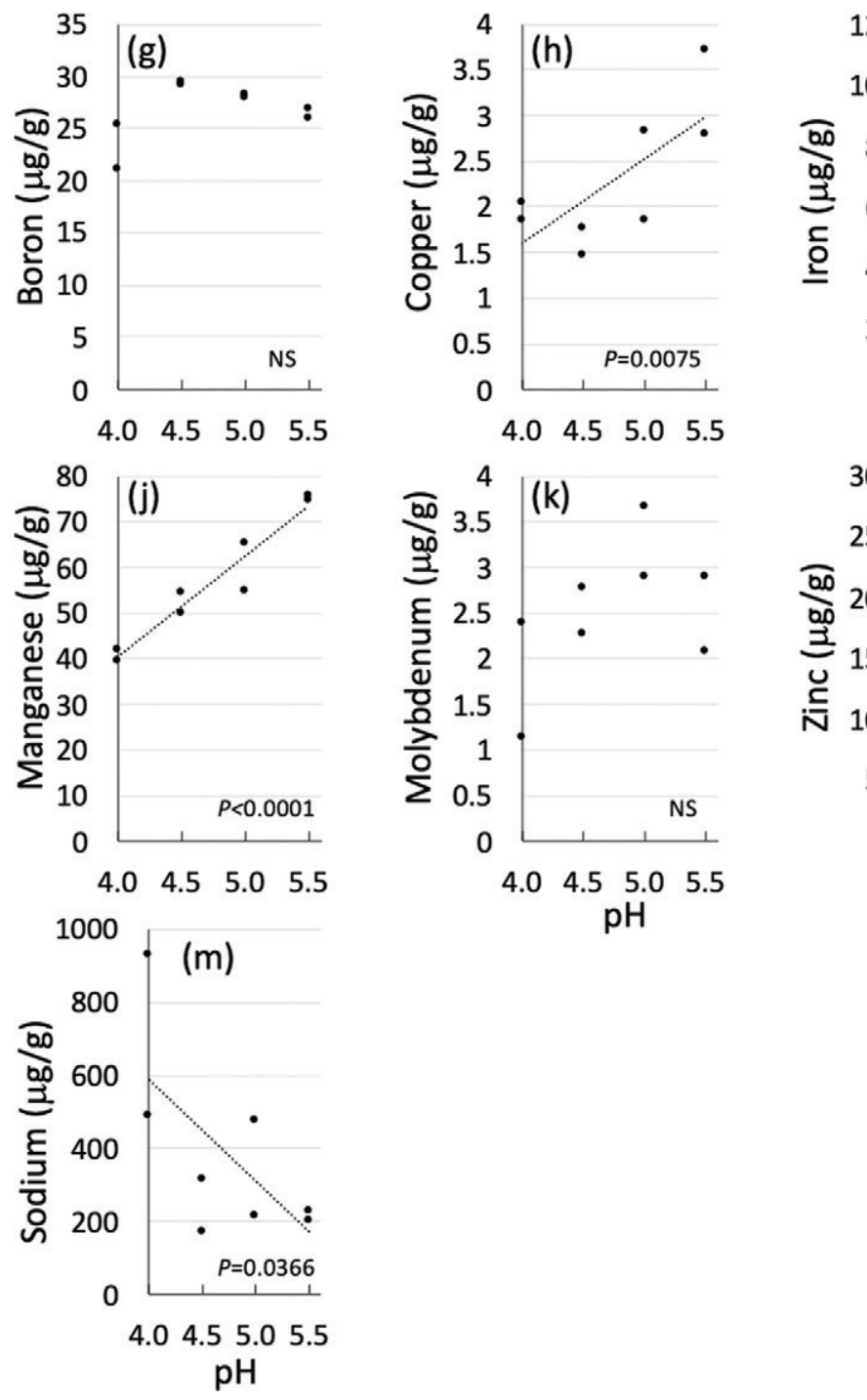

Fig. 2. (Continued).

and $1.6 \mathrm{~g}(65 \%), 0.31 \mathrm{~g}(53 \%)$, and $0.11 \mathrm{~g}$ $(79 \%)$ at $\mathrm{pH} 4.5$ of those at the standard $\mathrm{pH}$ $5.5(2.4,0.58$, and $0.14 \mathrm{~g})$, respectively. The reduction of leaf count by lowering $\mathrm{pH}$ was significant $(P<0.0001)$ but moderate magnitude ( $<25 \%$ reduction) than the biomass accumulation $(\approx 70 \%$ to $90 \%$ reduction). Plant leaf development is strongly affected by temperature (e.g., Walters and Currey, 2019), whereas plant biomass accumulation is determined by photosynthesis and leaf expansion, both of which are affected by plant nutrient status directly. Adversely effects of inadequate $\mathrm{pH}$ are well known in hydroponics nutrient management as $\mathrm{pH}$ affects availability of many essential nutrients for plant growth (Adams, 2002). For example, Arnon and Johnson (1942) showed that lettuce and tomato plants did not grow at $\mathrm{pH} 3.0$ and exhibited reduced shoot and root fresh weight at $\mathrm{pH} 4.0$ compared with $\mathrm{pH} 5.0$ or 6.0 .

In our experiment, spinach plants grown at $\mathrm{pH} 4.0$ showed yellowing of older leaves and were stunted. Their roots were contained within the small rockwool plugs and did not extend into the nutrient solution. In contrast, plants grown at $\mathrm{pH} 4.5$ extended roots showing normal morphology similar to those at standard $\mathrm{pH}$ 5.5. Therefore, we consider that the growth inhibition at $\mathrm{pH} 4.0$ was likely due to the direct damage by high hydronium ion concentrations, whereas that at $\mathrm{pH} 4.5$ was due to the indirect factors such as low nutrient uptake. In our earlier study, plant growth of two cultivars of sweet basil was unaffected by the same range of $\mathrm{pH}$ (4.0 to 5.5) (Gillespie et al., 2020). The growth response to $\mathrm{pH}$ is species specific and we need further studies to investigate responses to $\mathrm{pH}$ of commercially important cultivars and species grown hydroponically. Regardless, this was the first report showing spinach plant growth response to the acidic range of $\mathrm{pH}$.

Dry leaf tissue concentrations of N, P, K, $\mathrm{Mg}, \mathrm{S}, \mathrm{Cu}, \mathrm{Fe}, \mathrm{Mn}$, and $\mathrm{Zn}$ exhibited a significant decline as lowering $\mathrm{pH}$ (Fig. 2). The other elemental concentrations were either not significant $(\mathrm{Ca}, \mathrm{B}$, and $\mathrm{Mo}$ ) or increased (Na). Among these nutrients having the significant reduction by lowering $\mathrm{pH}, \mathrm{K}, \mathrm{Mg}$, $\mathrm{Cu}, \mathrm{Fe}, \mathrm{Mn}$, and $\mathrm{Zn}$ are taken up by the plants as cations and $\mathrm{N}\left(\mathrm{NO}_{3}-\mathrm{N}\right), \mathrm{P}$, and $\mathrm{S}$ are anions. Cation antagonism can be considered as a main factor affecting reduced uptake of cations under low $\mathrm{pH}$ (high hydronium ion concentrations) (Mengel et al., 2001; Peterson et al., 1982). Smith et al. (2004) also observed reduced cation concentrations in geranium plant leaves at low substrate $\mathrm{pH}$ and indicated competition between cations and hydrogen ions for root binding sites, low- $\mathrm{pH}$ stress on membrane and cation channel activity, or reduced uptake into the shoot tissue. Major macronutrients involved in cation antagonism in hydroponics are $\mathrm{NH}_{4}-\mathrm{N}, \mathrm{K}, \mathrm{Ca}$, and $\mathrm{Mg}$. In the present experiment, our nutrient solution did not contain $\mathrm{NH}_{4}-\mathrm{N}$ (all $\mathrm{NO}_{3}-$ $\mathrm{N}$ ), and all other cation concentrations (except $\mathrm{Ca}$ and $\mathrm{Na}$ ) declined with lowering $\mathrm{pH}$. Unlike other studies reporting recovery of growth by increasing $\mathrm{Ca}$ concentration at low pH (e.g., Arnon and Johnson, 1942) or a decline of $\mathrm{Ca}$ uptake as lowering $\mathrm{pH}$ (e.g., Gillespie et al., 2020), no clear responses of $\mathrm{Ca}$ concentration were observed in the present experiment. It is unclear why $\mathrm{Ca}$ uptake was unaffected by low $\mathrm{pH}$ for spinach but this is possibly due to the preference of $\mathrm{Ca}$ among the antagonistic cations for the Ca homeostasis in spinach. Of interest, Ferreira et al. (2020) showed a unique nutrient uptake of spinach plants under combinations of salinity (high $\mathrm{Na}$ ) and $\mathrm{K}$ deficiency, where spinach plants reduced $\mathrm{Ca}$ concentration by increased $\mathrm{Na}$ but not necessarily by increased $\mathrm{K}$ concentration in the nutrient solution. In our experiment, increasing $\mathrm{Na}$ as decreasing $\mathrm{pH}$ was also observed. According to Ferreira et al. (2020), Na was likely an essential mineral for the growth when $\mathrm{K}$ was deficient in the root zone.

Reduction of N, P, and S uptake under low $\mathrm{pH}$ may be more associated with overall root function. Tissue concentrations of N, P, and $\mathrm{S}$ were relatively similar between $\mathrm{pH}$ of $4.5-5.5$ and declined at a greater extent at the lowest $\mathrm{pH}$ (4.0) where plants were stunted. Therefore, the reduced uptake of these ions might be associated with the direct damage on roots by high hydronium ion concentrations.

In our earlier study (Gillespie, 2019), we had additional treatments examining adjusted micronutrient concentrations; we found significant reduction of $\mathrm{B}$ and $\mathrm{Mo}$, and in addition to those, we found significant reduction in the present experiment $(\mathrm{N}, \mathrm{P}, \mathrm{K}, \mathrm{Mg}, \mathrm{S}$, $\mathrm{Cu}, \mathrm{Fe}, \mathrm{Mn}$, and $\mathrm{Zn}$ ) with lowering $\mathrm{pH}$. Together, the growth reduction we observed in this experiment was likely due to the reduced nutrient uptake by the plants grown under low $\mathrm{pH}$. It should be noted that these overall reductions of nutrient uptake are different from what is reported for soil-based or soilless substrate-based systems. In these systems, typically toxicities of cationic metal ions occur at low pH (e.g., Peterson, 1982; Smith et al., 2004). In liquid-based hydroponics, due to the minimum use of substrates (only 15 to $20 \mathrm{~mL}$ volume of rockwool substrate against 4 to $5 \mathrm{~L}$ of nutrient solution per plant), interactions with cation exchanges with substrates virtually do not exist. Therefore, effects of $\mathrm{pH}$ on nutrient uptake in hydroponics 
are different compared with those in soil and soilless substrate culture.

Effects of increased nutrient concentrations on spinach growth and nutrient uptake under low pH (Expt. 2). Spinach plants in all four treatments $(\mathrm{pH} \times \mathrm{EC})$ exhibited normal growth without abnormal morphology or symptoms indicating nutrient disorders. However, as seen in Expt. 1, plant growth and development under low $\mathrm{pH} 4.5$ and standard EC 1.4 (marked as LP/SE) was largely reduced compared with those under the control (SP/SE) (Fig. 3). Fresh shoot and root, dry shoot and root mass, leaf count, and leaf area were reduced by $62 \%, 44 \%, 55 \%, 23 \%, 19 \%$, and $55 \%$, respectively, by lowering $\mathrm{pH}$ without altering EC of the nutrient solution. When nutrient concentrations and thereby EC were increased at low $\mathrm{pH}(\mathrm{LP} / \mathrm{HE})$, these plant growth parameters were significantly increased compared with standard EC at low $\mathrm{pH}$ (LP/ $\mathrm{SE}$ ), although they are still significantly lower than those of the control (SP/SE), except the dry root mass $(P=0.372)$. Increasing $\mathrm{EC}$ under the standard $\mathrm{pH}(\mathrm{SP} / \mathrm{HE})$ did not significantly increase plant growth and development compared with the control (SP/SE), suggesting that nutrient levels were sufficient and not limiting the growth of spinach under the standard $\mathrm{pH}$. In contrast, Öztekin et al. (2018) reported that the yield of spinach plants grown in a deep water culture system with a half strength of nutrient solution was $17 \%$ lower than that with a full strength solution $\left(\mathrm{mg} \cdot \mathrm{L}^{-1}\right.$; N 150, P 50, K 150, Ca 150, and Mg 50). Our macronutrient

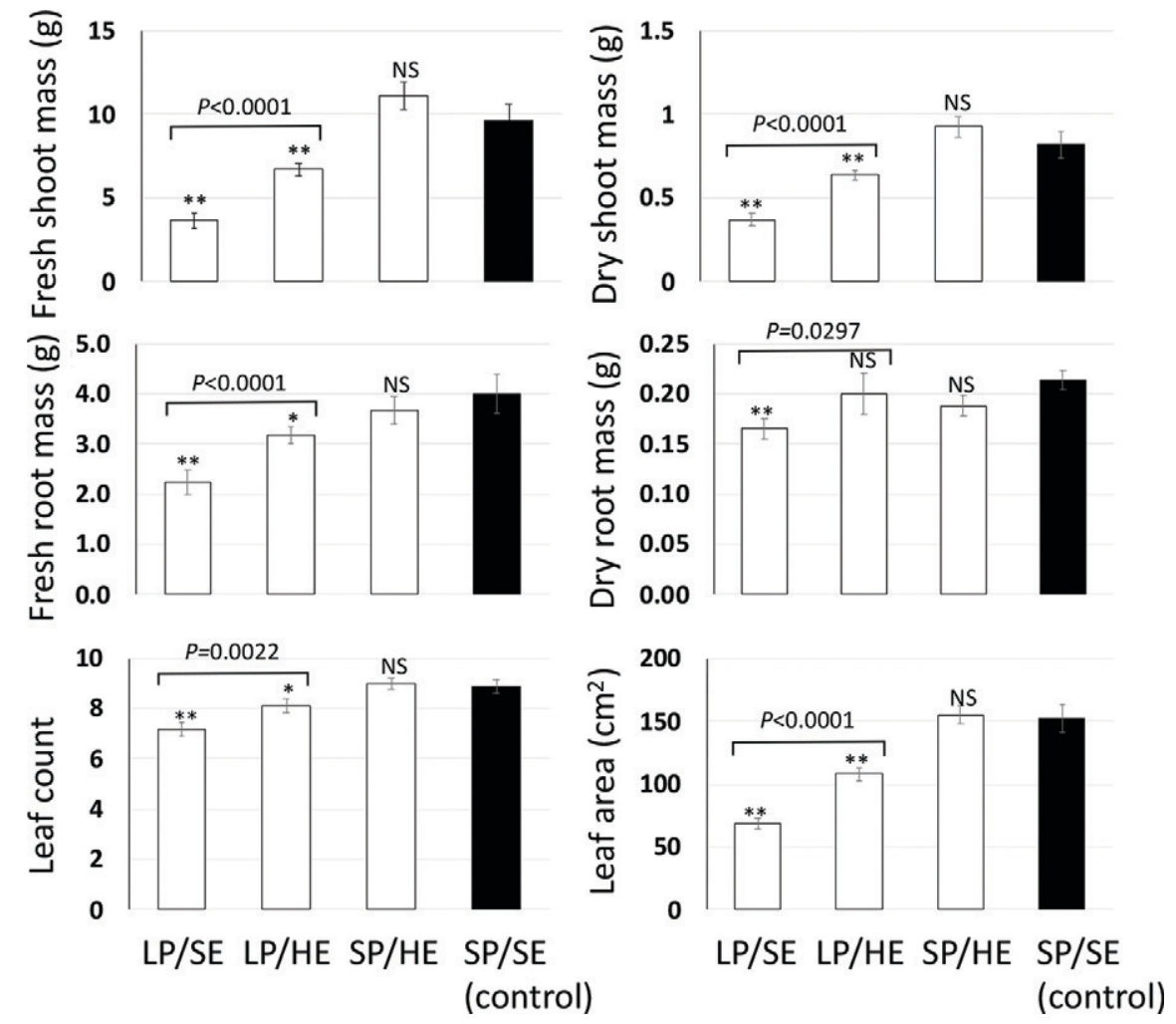

Fig. 3. Spinach plant growth as affected by high electrical conductivity (EC) when grown at low or standard $\mathrm{pH}$ of nutrient solution (Expt. 2). Means and SES $(\mathrm{n}=8)$. Pairwise comparisons by $t$ test with the control treatment (standard $\mathrm{pH}$ and standard EC) are shown (NS = nonsignificantly different at $P=0.05 ; *, * *=$ significantly different at $P<0.01$ or 0.05 , respectively). $P$ values of additional pairwise comparisons between standard and high EC at low pH (LP/SE vs. LP/HE) are shown. leaf nutrient concentrations except $\mathrm{K}, \mathrm{B}, \mathrm{Fe}$, and $\mathrm{Zn}$. Under low $\mathrm{pH}$ and increased EC treatment (LP/HE), all dry leaf nutrient concentrations were similar or higher than those of the control except $\mathrm{Mg}$ and $\mathrm{Zn}$, which showed a lower concentration than the control with a weak significance $(P=0.051$ and 0.056 for $\mathrm{Mg}$ and $\mathrm{Zn}$, respectively). Calcium concentration exhibited the largest increase by increased EC under low $\mathrm{pH}$ (LP/HE), reaching nearly $50 \%$ higher concentration of the control plants (SP/SE). This increased $\mathrm{Ca}$ uptake may have reduced uptake of antagonistic cations such as $\mathrm{Mg}$ by the roots and leaf tissue.

Magnesium is involved in numerous key functions in plants including photosynthesis and loading sucrose to phloem (Cakmak and Yazici, 2010; Guo et al., 2016). Leaf Mg concentrations of spinach plants grown in greenhouse were reportedly at $\approx 8$ to $10 \mathrm{mg} \cdot \mathrm{g}^{-1}$ without salinity (Ferreira et al., 2020). We did not notice a typical symptom of $\mathrm{Mg}$ deficiency in this experiment (e.g., interveinal yellowing of lower leaves). However, $\mathrm{Mg}$ deficiency-caused abnormal physiology may exist before a typical visual symptom appears. For example, Hermans et al. (2004) showed a large accumulation of sucrose in Mg-deficient plant leaves of Beta vulgaris before any loss in photosynthetic activity or reduction of biomass. Critical leaf $\mathrm{Mg}$ thresholds that cause yield reduction are species specific. Hauer-Jákli and Tränkner (2019) reported $\mathrm{Mg}$ thresholds of various crops species. Although spinach was not included in their report, the thresholds were shown in the range of 1 to $2 \mathrm{mg} \cdot \mathrm{g}^{-1}$, which is lower than the $\mathrm{Mg}$ concentrations observed in our experiment. Therefore, it is unlikely that our plants under LP/HE treatment are considered as exhibiting $\mathrm{Mg}$ deficiency. Nevertheless, further possible improvement of spinach plant growth at varied concentrations of $\mathrm{Mg}$ in the low $\mathrm{pH}$ nutrient solution is necessary.

Typical $\mathrm{Zn}$ deficiency reported for other species includes stunted growth with small leaves, which may be the result from loss of the capacity to produce significant amounts of auxin indole-3-acetic acid (Taiz and Zeiger, 2006). However, the spinach plants in this experiment did not show stunted growth in any of four treatments, and so it is unlikely that relatively low $\mathrm{Zn}$ is the main limiting factor of the plant growth. Moreover, $\mathrm{Zn}$ concentration of LP/HE treatment was similar level as that in SP/HE treatment, where plant growth was not significantly different from the control (SP/SE) (Table 4). Therefore, it is unlikely that the $\mathrm{Zn}$ was limiting the spinach growth under increased nutrient concentrations (LP/HE). However further optimization of nutrient formula with independently increased nutrients will help better understand the nutrient limiting spinach growth and means to recover the uptake and thereby overall growth of spinach plants. As nutrient uptake, especially $\mathrm{Ca}$ and $\mathrm{Mg}$, in leaf tissue is also enhanced by mass flow driven by transpiration, further investigation should consider environmental conditions such as high light, temperature, and 
VPD. Foliar nutrient applications are another approach shown as alternative means to increase $\mathrm{Mg}$ concentrations in spinach leaves when enhancing uptake by roots is a challenge (Borowski and Michalek, 2010).

Increasing EC under standard $\mathrm{pH} 5.5$ (SP/ $\mathrm{HE}$ ) increased $\mathrm{N}, \mathrm{Ca}, \mathrm{Cu}$, and $\mathrm{Mn}$ concentrations but did not affect the other nutrient concentrations (Table 4). As described earlier, these increases in $\mathrm{N}, \mathrm{Ca}, \mathrm{Cu}$, and $\mathrm{Mn}$ did not reflect plant growth as nutrient concentrations were generally sufficient in the standard $\mathrm{pH}$ conditions regardless of EC.

\section{Conclusion}

Spinach plant growth was significantly decreased by lowering nutrient solution $\mathrm{pH}$. Elemental concentrations of $\mathrm{N}, \mathrm{P}, \mathrm{K}, \mathrm{Mg}, \mathrm{S}$, $\mathrm{Cu}, \mathrm{Fe}, \mathrm{Mn}$, and $\mathrm{Zn}$ in plant leaves were lowest when grown in $\mathrm{pH}$ 4.0. Stunted growth was only observed in spinach grown in $\mathrm{pH}$ 4.0 , likely because of the direct effect of hydronium ion damage. Spinach grown in $\mathrm{pH}$ $4.5,5.0$, and 5.5 all displayed normal shoot and root growth, suggesting that reductions in shoot growth at $\mathrm{pH} 4.5$ and 5.0 were attributed to decreased nutrient uptake as opposed to the direct effect of $\mathrm{pH}$. Increased nutrient concentrations (EC $3.4 \mathrm{dS} \cdot \mathrm{m}^{-1}$ ) effectively increased the plant growth under low $\mathrm{pH} 4.5$ but did not fully recover the shoot fresh and dry weight compared with those of control plants (standard EC $1.4 \mathrm{dS} \cdot \mathrm{m}^{-1}$ and standard $\mathrm{pH}$ 5.5). Further optimization of individual nutrient concentrations need to be conducted to better understand the dynamics of nutrient uptake under low $\mathrm{pH}$, which may allow spinach to be grown without significant reductions in shoot growth in low $\mathrm{pH}$ as potential means of low-cost disease control.

\section{Literature Cited}

Adams, P. 2002. Nutritional control in hydroponics., p. 211-261. In: D. Savvas and H. Passam (eds.) Hydroponic Production of Vegetables and Ornamentals. Embryo, Athens, Greece.

Albright, L.D., R.W. Langhans, D.S. de Villiers, T.J. Shelford, and C.J. Rutzke. 2007. Root disease treatment methods for commercial production of hydroponic spinach. Final Report for the New York State Energy Research and Development Authority. Cornell University, Ithaca, NY.

Arnon, D.I. and C.M. Johnson. 1942. Influence of hydrogen ion concentration on the growth of higher plants under controlled conditions. Plant Physiol. 17:525-539, doi: 10.1104/pp.17.4.525.

Blaker, N.S. and J.D. MacDonald. 1983. Influence of container medium $\mathrm{pH}$ on sporangium formation, zoospore release, and infection of rhododendron by Phytophthora cinnamomi. Plant Dis. 67:259-263, doi: 10.1094/pd-67-259.

Borowski, E. and S. Michalek. 2010. The effect of foliar nutrition of spinach (Spinacia oleracea L.) with magnesium salts and urea on gas exchange, leaf yield and quality. Acta Agrobot. 63:77-83, doi: 10.5586/aa.2010.009.

Bugbee, B. 2004. Nutrient management in recirculating hydroponic culture. Acta Hort. 648:99-112, doi: 10.17660/actahortic.2004.648.12.
Cakmak, I. and A.M. Yazici. 2010. Magnisium: A forgotten element in crop production. Better Crops Plant Food 94:23-25.

Correll, J.C., B.H. Bluhm, C. Feng, K. Lamour, L.J. Toit, and S.T. Koike. 2011. Spinach: Better management of downy mildew and white rust through genomics. Eur. J. Plant Pathol. 129:193-205, doi: 10.1007/s10658-010-9713-y.

Dickson, R.W. and P.R. Fisher. 2019. Quantifying the acidic and basic effects of vegetable and herb species in peat-based substrate and hydroponics. HortScience 54:1093-1100, doi: 10.21273/ HORTSCI13959-19.

Ferreira, J.F., J.B. da Silva Filho, X. Liu, and D. Sandhu. 2020. Spinach plants favor the absorption of $\mathrm{K}^{+}$over $\mathrm{Na}^{+}$regardless of salinity, and may benefit from $\mathrm{Na}^{+}$when $\mathrm{K}^{+}$is deficient in the soil. Plants 9:507, doi: 10.3390/plants9040507.

Gillespie, D. 2019. Effects of low nutrient solution $\mathrm{pH}$ on hydroponic leafy green plant growth, nutrient concentration of leaf tissue, and Pythium zoospore infection. MS Thesis, Dept. of Horticulture and Crop Science, The Ohio State Univ., Columbus, OH. 23 May 2020. <http://rave.ohiolink.edu/ etdc/view?acc_num $=$ osu1563205720634412 >

Gillespie, D.P., C. Kubota, and S.A. Miller. 2020. Effects of low $\mathrm{pH}$ of hydroponic nutrient solution on plant growth, nutrient uptake, and root rot disease incidence of basil (Ocimum basilicum L.). HortScience 55:1251-1258, doi: 10.21273/HORTSCI14986-20.

Guo, W., H. Nazim, Z. Liang, and D. Yang. 2016. Magnesium deficiency in plants: An urgent problem. Crop J. 4:83-91, doi: 10.1016/j.cj. 2015.11.003.

Hauer-Jákli, M. and M. Tränkner. 2019. Critical leaf magnesium thresholds and the impact of magnesium on plant growth and photo-oxidative defense: A systematic review and meta-analysis from 70 years of research. Frontiers in Plant Sci. 10:766, doi: 10.3389 /fpls.2019.00766.

Hermans, C., G.N. Johnson, R.J. Strasser, and N. Verbruggen. 2004. Physiological characterisation of magnesium deficiency in sugar beet: Acclimation to low magnesium defferentially affects photosystems I and II. Planta 220: 344-355, doi: 10.1007/s00425-004-1340-4.

Ho, H.H. and C.J. Hickman. 1967. Asexual reproduction and behavior of zoospores of Phytophthora megasperma var. sojae. Can. J. Bot. 45:1963-1981, doi: 10.1139/b67-215.

Islam, A.K., D.G. Edwards, and C.J. Asher. 1980. $\mathrm{pH}$ optima for crop growth. Plant Soil 54: 339-357, doi: 10.1007/bf02181830.

Kong, P., G.W. Moorman, J.D. Lea-Cox, D.S Ross, P.A. Richardson, and C. Hong. 2009 Zoosporic tolerance to $\mathrm{pH}$ stress and its implications for Phytophthora species in aquatic ecosystems. Appl. Environ. Microbiol. 75: 4307-314, doi: 10.1128/aem.00119-09.

Mattson, N. 2018. Pythium root rot on hydroponically grown basil and spinach. eGro Edible Alert. Vol. 3.1. 23 May 2020. <https://e-gro. org/pdf/E301.pdf>.

Mengel, K., E.A. Kirkby, H. Kosegarten, and T. Appel. 2001. Nutrient uptake and assimilation, p. 111-136. In: Principles of Plant Nutrition. Kluwer Academic, Dordrecht, The Netherlands.

Öztekin, G.B., T. Uludag, and Y. Tüzel. 2018. Growing spinach (Spinacia oleracea L.) in a floating system with different concentrations of nutrient solution. Appl. Ecol. Environ. Res. 16:3333-3350, doi: 10.15666/aeer/1603_33333350.

Peterson, J.C. 1982. Effects of $\mathrm{pH}$ upon nutrient availability in a commercial soilless root medium utilized for floral crop production. $1 \mathrm{Feb}$. 2021. <https://kb.osu.edu/bitstream/handle/18 
11/70731/OARDC_research_circular_n268.pdf? sequence $=1$ \#page $=16>$.

Savvas, D. and N. Gruda. 2018. Application of soilless culture technologies in the modern greenhouse industry - A review. Eur. J. Hort. Sci. 83:280-293, doi: 10.17660/ejhs.2018/83.5.2.

Stanghellini, M.E. 1996. Efficacy of nonionic surfactants in the control of zoospore spread of Pythium aphanidermatum a recirculating hydroponic system. Plant Dis. 80:422.

Smith, B.R., P.R. Fisher, and W.R. Argo. 2004. Water-soluble fertilizer concentration and $\mathrm{pH}$ of a peat-based substrate affect growth, nutrient uptake, and chlorosis of container-grown seed geraniums. J. Plant Nutr. 27:497-524, doi: 10.1081/PLN-120028875.

Taiz, L. and E. Zeiger. 2006. Mineral nutrition, p. 73-94. In: Plant Physiology. Oxford University Press, Oxford, UK.

U.S. Department of Agriculture National Agricultural Statistics Service. 2014. 2012 Census of Agriculture. 25 June 2020. <https:// www.nass.usda.gov/AgCensus/ $>$.

U.S. Department of Agriculture National Agricultural Statistics Service. 2019. 2017 Census of
Agriculture. 25 June 2020. <https://www.nass. usda.gov/AgCensus/>.

Vlamis, J. 1953. Acid soil infertility as related to soil-solution and solid-phase effects. Soil Sci. 75:383-394.

Walters, K.J. and C.J. Currey. 2019. Growth and development of basil species in response to temperature. HortScience 54:1915-1920, doi: 10.21273/HORTSCI2976-18.

$\mathrm{Xu}, \mathrm{C}$. and B. Mou. 2016. Responses of spinach to salinity and nutrient deficiency in growth, physiology, and nutritional value. J. Amer. Soc. Hort Sci. 141:12-21, doi: 10.21273/JASHS.141.1.12. 